\title{
The Cause of the Interruption of Limitation in Chinese Civil Law:
}

\section{- Bringing a Lawsuit}

\author{
Hao Sun \\ Shandong University of Finance and Ecnomics, Jinan Shandong, 250014, China
}

Key words: limitation; interruption of limitation; the cause of the interruption

\begin{abstract}
As s basic system in the field of civil and commercial law, the limitation of action is directly related to the legal protection of civil rights. From the perspective of interest balance, there is a bridge between the obligees and the obligors. The system of limitation of action is one of the important contents, which affects the process of the limitation period of the obligee. It not only guarantees the long-term legalization of the existing state between the obligee and the obligor, but also prompts the obligee to exercise his own right. This article mainly discusses the issues related to bringing a lawsuit as one of the causes of the interruption of limitation.
\end{abstract}

\section{Introduction}

The system of limitation, also known the civil system, refers to: if the obligee does not exercise the right of claim to request the court to protect his right in a certain period, he will lose the chance of requesting protection of courts.

The limitation of action system is an ancient legal system of Roman law. The limitation of action system has been one of the most important issues since it was first established in the General Principles of the Civil Law of the People's Republic of China.

Owing to the calculating method of the limitation, the creditor may have a question like this: If the debtor has been delaying the time in purpose of non-payment, then the period of limitation is completed, their rights will be influenced. The legislators should give creditors the possibility of exerting an influence on the process of the limitation period so that the interests of the creditors can be properly protected. Therefore, the limitation system of litigation has come into being, which is an effective way to reasonably limit the system of limitation.

The interruption of limitation, which refers to that in the process of limitation, when statutory causes happens, the limitation shall be discontinued and a new limitation shall be counted from the time of the discontinuance.

There are articles about the causes of interruption in the General Principles of the Civil Law of the People's Republic of China: A limitation of action shall be discontinued if a suit is brought or if one party makes a claim for or agrees to fulfillment of obligations.

The Supreme People's Court made a further explanation and in the Provisions of the Supreme People's Court on Several Issues concerning the Application of Statute of limitations during the Trial of Civil Cases. The provisions of the interruption of limitation are more comprehensive.

The most effective way for the obligee to exercise his rights is to bring a lawsuit, and the prosecution is a statutory cause of interruption. The reason why the prosecution is one of the causes of the interruption of limitation is that the prosecution is the most powerful and effective way for the obligee to exercise his rights, not only requiring the obligor to fulfill his obligations, but also 
requiring the obligee in the formal procedures of the court to confirm it. This way to fully show that the obligee has been actively exercised their rights, not 'lying on the right to sleep'.

\section{The declaration of intention of the obligee need or not reach the obligor}

There are there different views about the time of interruption when it is caused by bringing a lawsuit.

The fact that the obligee exercises the right actively leads to the interruption of the limitation of action, and the act of the obligee to submit a complaint is sufficient to express their positive attitude to right protection.

In this view, submitting a complaint does not mean that civil proceedings have been initiated. A lawsuit includes the two actions, the obligee's act of submitting the complaint and the court's act of accepting the case. The court only hears the cases that meet all the statutory requirements. However, if the court dismissed the prosecution or not accepted, the limitation cannot be interrupted.

The reason is: The right of claim is the relative right and can only be realized by the counterpart's positive or negative actions. Therefore, when the obligor receives the obligee's intention of exercising his right, the limitation is interrupted. The counterpart of the right of claim is the obligor relative to the obligee, rather than the court, so submitting a complaint is just an action of exercising litigation rights. Only when the complaint is served by the court to the obligor, the obligor knows the fact that the other party actively advocates the right, and thus achieves the effect of the interruption.

According to the provisions of Article12 of the Provisions of the Supreme People's Court on Several Issues concerning the Application of Statute of limitations during the Trial of Civil Cases, if a party brings a suit or an oral complaint to a people's court, the limitation of action shall be interrupted from the date on which the complaint or an oral complaint is filed. It is obvious that China's legislation accepts the first point of view. There are several reasons why the Supreme Court took this view.

Firstly, the limitation of action shall be interrupted from the date of submission of the complaint or oral complaint and there is no violation of the legal principle of the Arrival Theory. It is quite different between the litigation claim and the request of the party. The declaration of intention of the claim has entered into force as soon as it arrives at the court. Otherwise, if the law prescribes that the limitation interrupts only when it reaches the obligor, it will cause the undue damage to the obligee when the delay is due to the court.

Secondly, the rules that the limitation interrupts from the date of submitting a written or oral complaint does not violate the principles that bringing a lawsuit needs two actions, the obligee's act of submitting the complaint and the court's act of accepting the case. The legislative purpose of the interruption of the limitation is to protect the obligee, so it can be appropriate to show a little partiality to the obligee.

\section{The moment of recalculating the limitation}

There are three views about the moment of recalculating the limitation.

The first view is: the limitation of action should be recalculated when the limitation interrupts. From the preceding discussion, the moment is submitting the complaint from.

The second point is that the limitation of action should be recalculated only after the court has made a substantive decision.

The third view is that the limitation of action should be recalculated after the expiration of the 
performance period determined by the court.

China takes the third view in judicial practice.

If the first point of view, it may produce such a situation that the court has not made a substantive judgment, but a new limitation has been completed first, which will undoubtedly damage the interests of the obligee.

If the second point of view, the court will generally determine the performance period in the judgment and during this period, the obligee cannot apply for enforcement and the obligor may does not fulfill his obligations. So it is unfair to the obligee and does not conform to the legislative purpose of the limitation of action if the performance period is included in the recalculated limitation.

Therefore, the new limitation should be calculated after the expiry of the performance period determined by the court.

\section{Withdrawal after bringing a lawsuit}

There is a considerable controversy that if the situation is a cause of Interruption or not. There are different understandings.

Some holds the negative point that if the obligee withdraw the lawsuit, it does not cause the interruption of limitation. Since the withdrawal is a complete denial of the claim, the rights of the parties should be restored to the state of non prosecution after the withdrawal. Therefore, the legal effect of the withdrawal after prosecution and the no prosecution are the same.

The second view is: the action of bringing a lawsuit has already stated that the obligee did not give up the right and was not too lazy to exercise his rights. The obligee withdraws the prosecution just because of a special reason. The reason for this view is that the limitation interrupts when the lawsuit is brought to the court and the interruption can not be recovered whether or not to withdraw.

\section{Prosecution was dismissed or not accepted.}

To bring a lawsuit as the legal cause for the interruption of the limitation of action which prescribed by law,was based on the legal requirements of the prosecution,as mentioned Above,although the prosecution does not fully meet the statutory requirements of prosecution,however, it can prove that the obligee is based on the right to claim the rights of the obligor in the form of litigation.Therefore, it is not right that any prosecution of the obligee can be the cause of the interruption of the limitation of action.However, the relevant judicial interpretations of the Supreme People's court and relevant provisions of the General principles of civil law of people's republic of china.And there are different understandings among the jurisprudential circle and judicial practice.

The first view:the prosecution can not take effect of limitation of action after the prosecution of the obligee has been decided not to accept or be dismissed, it does not cause the interruption of prescription.Because the obligee's prosecution does not meet the statutory requirements, when a lawsuit is decided not to accept or reject the lawsuit,equivalent to the obligee did not prosecute from the beginning,therefore it does not cause the interruption of prescription.

The second view: after the prosecution was found to be rejected or dismissed,it does not cause the interruption of prescription,but if the obligee has filed a new suit within 6 months,the limitation of action may be regarded as a breach of the previous proceedings. The reason for this view is:It proves that the obligee's prosecution meets the conditions of legal prosecution, while the obligee file a new suit which has accepted by court within 6 months, 6 months is very short,therefore the first prosecution can be regarded as a cause of limitation. 


\section{Reference}

[1] Wang Jing, "China’s lawsuit intermediation system" [D]. Dalian: Dalian Maritime University, 2013.

[2] Wei Zhenying. "Civil Law General" [M]. Beijing: Peking University Press, 2010.

[3] Yan Qingsheng. "China’s laws and regulations of the mechanism of aging obstacles" [D]. Chongqing: Southwest University of Political Science and Law, 2010.

[5] Chu Duan. "On the abandonment of the interests of civil law in China" [J]. Legal and social, 2008.

[6] "the Supreme People's Court on the trial of civil cases applicable to the limitation of the system of a number of issues".2008. 